Tempo Social; Rev. Sociol. USP, S. Paulo, 12(1): 141-164, maio de 2000.

\title{
O passado ameaça o futuro Tocqueville e a perspectiva da democracia individualista
}

\author{
FERNANDO MAGALHÃES
}

\begin{abstract}
RESUMO: A história da democracia, nos tempos modernos, tem coincidido, de modo geral, com a história da democracia americana. Desde que Tocqueville demonstrou a força irresistível dessa forma de governo, as sociedades ocidentais têm se esforçado para adotá-la como modelo. Ela representa, para a grande maioria do homem contemporâneo, o único tipo de regime político capaz de conduzir o indivíduo a seu pleno desenvolvimento - à conquista da liberdade pessoal e da igualdade de condições. Contudo, esse desenvolvimento "igualitário" é responsável, também, pelos aspectos negativos do seu funcionamento. A democracia corre o risco de se transformar em sua própria antítese, comprometendo seu próprio sistema de duas maneiras: pela atuação de seus agentes e pelo seu conteúdo individualista especificamente excludente. O presente trabaIho procura expor, de forma concisa, não apenas as preocupações de Tocqueville com os destinos dessa forma de governo, mas também como a igualdade de condições, isolada de um conteúdo material (social), pode gerar uma espécie de discriminação que torna a sociedade democrática violenta e injusta.
\end{abstract}

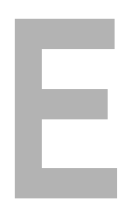

m um ensaio escrito acerca de duas décadas, Norberto Bobbio celebra, com satisfação, o interesse despertado na esquerda pelas obras de John Stuart Mill (cf. Bobbio, 1986, p. 107-113). Nos últimos tempos, um outro pensador liberal, contemporâneo de Mill, tem despertado a atenção da esquerda - inclusive de uma parte da esquerda marxista que sempre esteve voltada para as questões relativas à democracia e à liberdade -, que procura exumar seus escritos, atribuindo-lhes uma fundamental
UNITERMOS:

democracia, individualismo, liberdade, Alexis de Toqueville.

Professor do Departamento de Filosofia do CFCH - UFPE 
importância para a compreensão da realidade atual. Trata-se do sociólogo francês Alexis de Tocqueville, que dedicou seus trabalhos a uma intensa preocupação com a possibilidade da democracia transformar-se em seu próprio algoz, tendo em vista o excessivo peso concedido pelas sociedades modernas ao seu poder majoritário. De fato, esse "renovado interesse" pelo pensamento de Tocqueville não é desprovido de sentido quando se sabe que o mundo contemporâneo passa por condições históricas as quais ele antecipou em mais de um século e meio, e que merece uma investigação mais profunda.

A análise da obra de Tocqueville sugere, portanto, a procura, antes de qualquer outra coisa, de respostas para suas inquietações - ainda hoje válidas - sobre o perigo que pode representar, para os Estados modernos, o desenvolvimento incontrolável do chamado processo democrático "individualista". Adjetivei deliberadamente o conceito de democracia para diferenciá-lo do modelo denominado "socialista" que durante muito tempo marcou o debate nas teorias sociais. Contudo, a crítica que Tocqueville faz ao nascente regime político na América - isto é, à possibilidade de edificação de um "pensamento único" que impeça o desenvolvimento da liberdade no interior do sistema, opondo obstáculos às ações da minoria - provavelmente poderia se aplicar também às estruturas econômico-políticas que até bem pouco vigoraram nos países do Leste Europeu.

Mas existem boas razões para evitar, aqui, a discussão desse problema. Em primeiro lugar, há diferenças essenciais entre o fenômeno descrito por Tocqueville, no século passado, e o protótipo de sociedade instaurado nos exEstados de orientação soviética. A formação social desses sistemas sustenta-se sobre pilares basicamente coletivistas, em que o indivíduo perde sua autonomia em função do conjunto da organização social. Não há espaço para o desenvolvimento do individualismo, bem como toda esfera econômica é, praticamente, objeto de controle estatal. Quer dizer, presume-se uma forma de democracia (econômica) diversa daquela observada e estudada por Tocqueville. Em segundo lugar, e como se sabe, as análises de Tocqueville incidem sobre um tipo específico de democracia, aquele que se encontra em construção no jovem Estado americano e que, segundo nosso autor, iguala todos em oportunidade.

É, portanto, a democracia tocquevilleana de "igualdade de condições” - e não a democracia econômica - que precisa ser investigada, e para a qual as respostas encaminhadas pela esquerda, inclusive a esquerda marxista, não são totalmente satisfatórias. Ocupada durante um longo período com o problema da igualdade material, a esquerda refugia-se nas trincheiras mais recônditas do terreno social e econômico sem se dar conta de que se transforma, aos poucos, não no coveiro da burguesia, mas do proletariado. Com isso negligencia, consideravelmente, a contribuição do pensamento liberal naquilo que poderia ter sido a fórmula salvadora do regime socialista: a chamada liberdade política. A esquerda paga, desse modo, um preço excessivamente alto por descobrir, tardiamente, que uma parte da crítica liberal à ditadura das massas não se dirige apenas ao socialismo.

A crítica liberal a certos aspectos do conceito de liberdade - pelo 
menos na variante de alguns de seus pensadores, Tocqueville à frente - aplicase também (sobretudo no caso deste último), à democracia denominada burguesa e ao individualismo das sociedades modernas. Nesse sentido, a sociologia e a ciência política de Tocqueville possuem fundamental importância para a compreensão da época em que vivemos. Somos herdeiros de um pensamento que, em suas linhas gerais, ainda é o mesmo que serviu de objeto para as análises de Tocqueville; e tudo indica que muitas de suas preocupações no que concernem à tirania da maioria não perdem a validade nos dias correntes. É o suficiente notar os rumos que toma o processo de democratização em todo o mundo para se chegar à conclusão do perigo que pode resultar, para todos nós, da formação de um pensamento único - isto é, de um planeta presidido por uma ideologia que esmaga as minorias em nível nacional e internacional.

Percebe-se claramente - embora muitos fechem os olhos imaginando tratar-se de uma miragem passageira - o que esse tipo de democracia, que tanto espanto causa a Tocqueville, é capaz de produzir. A repressão às minorias étnicas e raciais é comum nos Estados Unidos e na Europa (cf. Hall, 1998 , p. 85) ${ }^{1}$-apenas para nos situarmos no mundo ocidental -, e o individualismo extremado tem levado populações inteiras ao desespero e a filosofia ao irracionalismo, à quintessência da razão calculadora. Não surpreende, pois, que as teorias dominantes no campo filosófico enfatizem exageradamente a importância da consciência individual para a teoria do conhecimento (a subjetividade é hoje o foco das atenções dos filósofos), e a sociologia (em conjunto com a mesma filosofia) preconize o fim do social e a atomização do homem nas sociedades pós-modernas (cf. Baudrillad, 1978). Naturalmente tenho que admitir, como faz Tocqueville há mais de 150 anos, que esta é uma realidade à qual estamos indiscutivelmente presos. A democracia é um fato concreto na vida dos homens e mulheres neste final de milênio, e nada leva a acreditar que ela se sinta ameaçada em seus aspectos vitais.

Aparentemente irreversível, a democracia individualista, como a conhecemos em nossos tempos, parece estar destinada, por alguma espécie de fatalismo histórico, a se perpetuar indefinidamente. Essa tese finalista ${ }^{2}$ tem, certamente, muitos adeptos; o que não significa que exista uma concordância generalizada em torno de uma definição de democracia. Muito pouca gente, porém, discorda de sua importância e até mesmo da natureza universal do seu valor. $\mathrm{O}$ problema é saber se essa conquista da modernidade, que tanto atormenta Tocqueville, terá capacidade para estimular o progresso social ou se, de outro modo, poderá produzir uma forma de governo que, ao invés de promover o acesso de todos ao bem estar geral, conduza a sociedade a uma espécie de segregação em que a maioria exerça sobre a minoria um despotismo incontrolável de sorte a impedir a sua participação nos processos de decisão. Será a democracia como igualdade de condições - mesmo com as restrições e ressalvas feitas por Tocqueville - fator suficiente para tornar a vida social de todos os membros de uma comunidade aceitável segundo parâmetros que abstratamente poderíamos designar como o mínimo de dignidade oferecida ao ser humano?

Este estudo parte do pressuposto de que a anatomia político-social
1 Stuart Hall chama atenção para a "reação defensiva daqueles grupos étnicos dominantes que se sentem ameaçados pela presença de outras culturas", a exemplo do que ocorreu no Reino Unido, produzindo uma atitude mesquinha que chamou de "inglesidade" (englishness).

${ }^{2}$ Uma tese com a qual Tocqueville parece simpatizar. Num discurso pronunciado na Assembléia Constituinte, em 12 de outubro de 1848, ele deseja que a revolução que se desencadeia na França seja não só liberal como a última, a concretização dos ideais da Revolução Francesa (cf. Tocqueville, 1988, p. 163-164). 
do regime democrático individualista, radiografada por Tocqueville entre os anos de 1835 e $1840^{3}$, merece, seriamente, ser levada em consideração. Ela mostra, efetivamente, uma tendência à padronização dos indivíduos e sua inevitável consequiência: unificação do pensamento político-social e sua ação quase tirânica sobre as minorias. Tocqueville tem clara consciência das inclinações despóticas desse sistema, e por isso apresenta sua proposta de moderação dos apetites individuais como forma de evitar que a liberdade seja sacrificada em nome da igualdade. Ele se vale, para esse fim, do recurso a uma instituição cujo papel é fazer com que a democracia funcione sem a perda da liberdade. E vai encontrar esse instrumento numa instituição análoga à aristocracia.

O problema que se coloca, então, é o seguinte: até que ponto os meios escolhidos por Tocqueville correspondem, coerentemente, ao seu empenho para obstar a esmagadora pressão da multidão sobre a minoria indefesa? Em outras palavras, será essa "nova aristocracia" suficientemente eficaz para opor obstáculos ao avanço do "despotismo democrático" nas sociedades modernas? Assim, o objetivo deste trabalho é demonstrar que, a despeito das corretas advertências de Tocqueville para a ameaça que representa a ampliação mundial da democracia individualista, e da importância da criação de um mecanismo que busque o equilíbrio entre a igualdade e a liberdade, a eficácia desse instituto fracassa diante da lógica dos seus argumentos. E por dois motivos. Um deles relaciona-se ao próprio conceito de democracia em Tocqueville. Trata-se de uma concepção limitadora e excludente de determinada forma de governo, vista sob a ótica exclusiva da defesa dos interesses privados.

O outro motivo diz respeito à "fórmula formal” de sua concepção de instrumento moderador. A noção tocquevilleana de aristocracia moderna, ou melhor, de um aparato a ela análogo, fundamenta-se numa duplicidade em que uma ação anula a outra. A idéia de um corpo de juristas como contraponto ao ideário de igualdade choca-se com a visão de que os membros do Judiciário também são influenciados pela doutrina dominante na América: a doutrina do interesse individual que predomina na opinião pública (cf. Tocqueville, 1986). Dessa forma, a democracia, na acepção tocquevilleana do termo, dificilmente conseguirá evitar a opressão da maioria e oferecer condições de vida adequada e liberdade à minoria; ao mesmo tempo, manterá a própria maioria sob o jugo de um pensamento totalizante e apático, o que pode provocar a revolta das camadas oprimidas. Para demonstrar meu propósito preciso, antes de mais nada, expor, resumidamente, as concepções de Tocqueville sobre democracia e liberdade.

\section{O espírito da democracia e a necessidade da liberdade}

${ }^{3}$ Datas da publicação, respectivamente, dos dois livros de $A$ democria na América.

${ }^{4}$ Pierre Gilbert, Introdução Biográfica (Tocqueville, 1988, p. 12).
Já se observou que é difícil encontrar, nas obras de Tocqueville, uma definição breve e definitiva de democracia, e que, por isso, essa definição deveria ser "buscada ou perseguida"4. De fato, Tocqueville não nos dá uma conceituação precisa do termo. Embora ele recorra a diversas construções metonímicas para exprimir sua compreensão desse fenômeno que começa a surgir na América - igualdade de condições, desenvolvimento gradual e progressi- 
vo da igualdade, governo em nome do povo etc. (cf. Tocqueville, 1986, p. 43-44 e 177) -, seu significado mais provável é o de uma sociedade uniformizada (cf. Tocqueville, 1986, p. 648), padronizada, de indivíduos alheios uns aos outros em contraposição à estrutura hierarquizada e estratificada - mas de certa forma comunizada - da sociedade feudal. Tocqueville sente que os laços que mantêm os indivíduos unidos entre si, no regime aristocrático, tendem a romper-se integralmente deixando os homens entregues às suas próprias paixões. Ele lamenta a quebra dos antigos vínculos não por uma atitude conservadora, mas porque receia que, livres de toda responsabilidade para com seus semelhantes, e ocupados exclusivamente com seus interesses pessoais, os indivíduos se entreguem a um perigoso conformismo, aceitando docilmente todas as regras sociais impostas pelo individualismo. Essa passividade ${ }^{5}$ certamente produz um comportamento de indiferença para com a gestão da coisa pública, permitindo, assim, que a representação majoritária exerça um autoritarismo de novo tipo sobre a minoria; autoritarismo este exercido com o consentimento popular, o chamado, "despotismo pelo consentimento do povo"6. A apreensão com a possibilidade das paixões manifestarem-se livremente acompanha Tocqueville em toda a Democracia na América. Na Introdução ele argumenta que a democracia foi abandonada a seus instintos selvagens e que a revolução democrática operou-se sem que se fizesse nos costumes uma transformação para que a revolução se tornasse útil (cf. Tocqueville, 1986, p. 44-45).

O que fazer para que o curso natural dos acontecimentos não acabe por conduzir a democracia ao seu leito despótico - a tarefa consiste em "educar a democracia", como ele mesmo diz ${ }^{7}$ é, talvez, o cerne do pensamento de Tocqueville ${ }^{8}$.É verdade que ele não pretende julgar "a revolução democrática em marcha" (Tocqueville, 1986, p. 49); mas também não é menos certo que, se seu desejo é encontrar ensinamentos dos quais possa tirar algum proveito, a democracia, como se apresenta a seus olhos, seguramente inclina-se para uma espécie de tirania. Nesse aspecto, a teoria tocquevilleana é ambivalente. Vê a possibilidade de um despotismo estender-se globalmente (cf. Tocqueville, 1986, p. 648), como uma forma de infecção a contaminar corpos sociais em todo o mundo; simultaneamente, porém, enxerga em algumas instituições americanas o antídoto para a cura da doença. Essa tensão, presente em quase toda A Democracia na América, é fruto da situação conflituosa em que se encontram os Estados Unidos à época. Fazia menos de 50 anos que a Constituição fora promulgada, e as seqüelas não haviam desaparecido inteiramente. Tocqueville descreve, inclusive, as diferenças de características entre os habitantes do Norte e do Sul. O próprio sistema político equilibra-se entre formas de participação direta e indireta, e os interesses navegam entre o público e o privado, ainda que este predomine sobre aquele. A incerteza povoa o pensamento de Tocqueville. Prevalece, contudo, em suas análises, o temor de que uma nova linhagem de tiranos ocupe o espaço que a democracia não soube preencher. É para esse vazio a ser completado que se voltam as atenções de Tocqueville.

Sua expectativa é de que alguma instituição nascente cumpra um papel similar ao da aristocracia no antigo regime. Essa camada social, pelos estrei-
5 Tocqueville chama a isso de servilité (servilidade) (cf. Tocqueville, 1986, p. 45).

${ }^{6}$ Sobre isto cf. o artigo de Ernst Vollrath, $O$ Despotismo Ocidental (apud Jasmin, 1991, p. 51).

7 "Educar (instruire) a democracia (...) purificar seus costumes, regular seus sentimentos, substituir pouco a pouco sua inexperiência pela ciência dos negócios (...): tal é o primeiro dos deveres impostos em nossos dias àqueles que dirigem a sociedade" (Tocqueville, 1986, p. 44).

8 "Dado que a igualdade indicaria um processo geral, comum a todos e irreversível, a variação estaria na história da liberdade" (Werneck Vianna, 1993, p. 177). 
tos laços que mantém com a família e o lugar em que vive, termina por criar, voluntariamente, deveres entre os indivíduos e ligar cada homem a vários de seus cidadãos (cf. Tocqueville, 1986, p. 496). Vínculo que tem por efeito a capacidade de colocar obstáculos ao isolamento social, ao mesmo tempo que conduz os homens à dependência uns dos outros. Evita, com isso, o individualismo, e faz com que se mostrem freqüentemente dispostos a se esquecerem de si próprios (cf. Tocqueville, 1986, p. 497). Essa tendência a sacrificar os prazeres pessoais e a pensar o bem comum é a condição sine qua para impedir o desenvolvimento do despotismo. Unidos, os indivíduos tornam-se fortes o bastante para limitar as ameaças por parte do poder. Não estranha, portanto, a atenção que Tocqueville dedica às associações, esses corpos intermediários que denominamos hoje - pelo menos alguns deles - de "sujeitos coletivos". Deriva, portanto, do fortalecimento desses grupos, particularmente dos segmentos ligados à criação das leis, o significado da palavra liberdade. A exemplo do que ocorre com a democracia, aqui, também, não existe uma definição precisa para essa categoria sociológica e filosófica - não há lugar, no pensamento do escritor gaulês, para a compreensão de liberdade como categoria econômica. Da mesma forma que para Tocqueville democracia é quase sinônimo de igualdade, liberdade é identificada com a ausência de coerção, o que, de resto, em nada difere do conceito de liberdade negativa em tantos outros liberais. Ela se mostra, na opinião de Tocqueville, um instrumento inibidor que pode moderar a coação sobre os indivíduos (cf. Tocqueville, 1986, p. 243).

Inegavelmente, há outras características que Tocqueville empresta ao conceito de liberdade. Associá-la ao critério de justiça é um deles, e observamos, até mesmo, uma vaga noção do conteúdo positivo do termo quando contrapõe o estabelecimento da igualdade na sociedade civil - em que todos têm o direito de entregar-se aos mesmos prazeres - à instauração da igualdade no mundo político - onde nem todos tomam parte no governo (cf. Tocqueville, 1986, p. 242 e 493). Essas passagens no texto, porém, são escassas, para não dizer, únicas. O tom dominante em praticamente toda a sua obra encontra-se na forma de garantir os direitos individuais e opor resistência ao abuso do poder (cf. Tocqueville, 1986, p. 243 e 323). Em O Antigo Regime e a Revolução, Tocqueville sustenta que "as instituições livres não são menos necessárias aos principais cidadãos do que aos cidadãos menores para que aprendam os perigos a que estão submetidos e possam, assim, assegurar seus direitos" (Tocqueville, 1986, p. 1038). Desse modo, a proteção contra o abuso do poder e a garantia dos direitos individuais encontram-se, em Tocqueville, como já mencionei, em uma instituição análoga à aristocracia antiga, função que ele atribui às associações intermediárias, especialmente à magistratura. (Voltarei a este tema mais adiante). Colocadas essas premissas, resta saber se o modelo de democracia estudado por Tocqueville e a fórmula por ele encontrada para atender às exigências do critério de liberdade tendem a conciliar as duas categorias e, conseqüentemente, reprimir o ímpeto individualista que conduz a sociedade ao conformismo e ao sentimento de indiferença. Antes, porém, convém dedicar algumas palavras ao esforço que faz Tocqueville para situar o espírito americano, dividido 
que está entre os interesses privados e os negócios públicos, porque é devido ao afastamento dos princípios que regem um estilo de vida próprio às sociedades antigas que Tocqueville vai tematizar a problemática da liberdade.

\section{O enfraquecimento do halo público}

Quando Tocqueville escreve sua obra mais célebre, a democracia americana, como formulada pelos pais fundadores da nação, está começando a ensaiar seus primeiros passos. Embora tenham passado quase cinqüenta anos desde os eventos da Filadélfia ${ }^{9}$, não se pode dizer que o desenho institucional imprimido pela revolução esteja definitivamente consolidado. As disputas internas entre federalistas e antifederalistas mantêm-se firmes, e a posterior eclosão da Guerra de Secessão é apenas uma mostra - ainda que a mais dramática - da divisão entre republicanos e defensores da ordem federativa. Tocqueville se dá conta das profundas implicações desse embate político e reconhece uma certa dualidade no comportamento dos americanos. Ora a balança pende para as decisões em praça pública, ora inclina-se para o instituto da representação. Apesar disso, não está inteiramente consciente das contradições que isso pode causar à sua teoria.

O corolário desse amálgama democrático é que, com a evolução do processo em direção ao sistema representativo, prevalece, no fundo, sempre a opinião de uma minoria; bastante incisiva, porém, para envolver, praticamente, toda a nação. Tem-se a impressão, assim, de que a maioria participa realmente das decisões ${ }^{10}$. Passados um século e meio desde o aparecimento do texto tocquevilleano, nota-se, perfeitamente, um acentuado grau de decisões por via indireta e um crescente avanço do individualismo. À medida que o envolvimento com os negócios públicos torna-se raro, e o indivíduo cada vez mais apega-se à esfera privada, seu sentimento comunitário é afetado pelo interesse pessoal; e sua relação com outros indivíduos é nada mais que o reflexo das próprias relações sociais. O resultado é a perda da substância que confere a capacidade de resistir: a autonomia (liberdade). O relacionamento entre democracia e liberdade permanece, portanto, insolúvel e exige um sério compromisso com o exame dos mecanismos e das raízes de um estilo de vida que, queiram ou não os mais resistentes adversários de uma forma particular de exercitar o poder na modernidade, torna-se efetivamente irreversível. O mais interessante é perceber a apropriação desse way of life por parte de um segmento do pensamento filosófico e político que, a exemplo do aristocrata francês do século XIX, procura, obstinadamente, demonstrar a inevitabilidade da "democracia liberal" através da experiência que se desenvolve no mundo contemporâneo.

Penso, particularmente, nas análises de um personagem relativamente novo no âmbito das ciências sociais: o ex-assessor do Departamento de Estado norte-americano, Francis Fukuyama. Observando os acontecimentos recentes, que apontam presumivelmente para o fim do socialismo, Fukuyama (1992) adota uma posição próxima àquela que Tocqueville anuncia na primeira metade do século passado: a igualdade chega às nações pela via da
${ }^{9}$ Estado onde se realizou a Convenção que elaborou a Constituição e forjou o federalismo americano.

10 "O comparecimento sazonal às urnas, que constitui regra elementar da sociedade democrática, é insuficiente e enganador, pois ocorre num contexto de menoridade política" (Jasmin, 1991, p. 51). 
${ }^{11} \mathrm{Cf}$. especialmente o Livro I, Parte II, Cap. V, p. 222-225. Para uma análise das circunstâncias geográficas em relação à fraqueza dos regimes democráticos em Tocqueville (cf. Lipson, 1966, p. 83-84).

12 Tocqueville está convencido de que cedo ou tarde a França - e com ela toda a Europa atingirá, "como os americanos, a igualdade quase completa de condições" (Tocqueville, 1986, p. 49). democracia burguesa, uma vez que já não encontra inimigos à sua porta. Acabada a "guerra fria", os Estados Unidos podem se dedicar menos à defesa e mais a outras necessidades (como de resto, todo o mundo ocidental). Tocqueville atribui - entre diversos fatores - à ausência de vizinhos poderosos, a igualdade que se estende por toda a América. A fraqueza dos governos democráticos na condução dos negócios externos impele-os a cuidarem dos seus próprios problemas internos (cf. Tocqueville, 1986) ${ }^{11}$. Não quero dizer com isso que o problema central das análises de Tocqueville está condicionado à localização geográfica, mas que entre outras coisas fornece elementos para que se interprete a idéia de igualdade a partir da inexistência de inimigos em suas fronteiras. O termo fronteira passa a adquirir, então, uma amplitude que ultrapassa circunstâncias regionais e se insere no interior de concepções ideológicas. Numa época em que proliferam armas nucleares, por exemplo, e o risco de uma ogiva atingir um território a milhares de quilômetros de distância não é mera especulação, o conceito de "fronteira" torna-se claramente elástico.

Tocqueville escreve, nitidamente, sobre uma forma particular de democracia - a democracia americana. Mas isso não significa que ele restrinja seu desenvolvimento apenas ao Novo Mundo. Trata-se, na verdade, de algo novo, universal, extensivo a todas as sociedades civilizadas e, portanto, um fato providencial que escapa ao poder humano (cf. Tocqueville, 1986, p. 43). A afirmação de Tocqueville não é fortuita e não pode mesmo ser atribuída meramente à sua religiosidade, se bem que esta seja o testemunho de como se deve medir a política por um desígnio de Deus. O "estado social imposto pela Providência" (Tocqueville, 1986, p. 44) é o resultado efetivo de um processo que não encontra sua compreensão à margem do elemento religioso. Isso porque o puritanismo, seita à qual se filiam os "pilgrims", primitivos emigrantes que desembarcam no Continente americano nas primeiras décadas do século XVII, longe de ser exclusivamente uma doutrina religiosa, confunde-se, em vários pontos, com as teorias democráticas e republicanas (cf. Tocqueville, 1986, p.64). Relacionando a política à religião, Tocqueville pode, então, sustentar a idéia de que a inevitabilidade do domínio democrático é um desígnio de Deus e contra ele é impossível lutar. Aceitando esse princípio como definitivo, não resta ao pensador francês outra coisa que resignar-se com a realidade que acredita ser o futuro da humanidade. Tal movimento social dificilmente será detido pelos seus fracos adversários (cf. Tocqueville, 1986, p. 43-44).

A certeza da evolução contínua da democracia cruzando o oceano e alcançando inapelavelmente o continente europeu ${ }^{12}$ não lhe traz ilusões. Nem mesmo parece ser seu propósito julgar se a revolução social, na sua "marcha irresistível", é vantajosa ou prejudicial à humanidade (cf. Tocqueville, 1986, p. 49). Tocqueville vê, na igualdade americana, mais do que a própria América. Procura a "imagem da democracia, suas inclinações, seu caráter, seus preconceitos e suas paixões; eu quero conhecê-la para saber ao menos o que devemos esperar ou temer dela" (Tocqueville, 1986, p. 49). Durante quase um ano Tocqueville observa, empiricamente, o funcionamento das instituições americanas, não raro admirando-se da forma pela qual o poder é exercido, 
sobretudo na região da Nova Inglaterra. Ali ele encontra um sistema de participação política que lembrava a antiga Atenas, onde a representação não era admitida (Tocqueville, 1986, p. 71).

Esse método democrático de participação tem sua fonte na própria construção do Estado americano, cujas raízes podem ser encontradas nos primeiros grupos de emigrantes que compõem as treze colônias iniciais. $\mathrm{O}$ novo modus vivendi societário não chama a atenção de Tocqueville somente pelo seu procedimento, isto é, a participação direta, através de assembléia como na antiga Grécia; o que atrai, sobretudo, Tocqueville, é a fixação num projeto que contamina todos quase sem exceção. Naturalmente, o processo democrático americano, até a época de Jackson, permite a um observador com conhecimentos a respeito dos valores e costumes da época medieval, fazer um paralelo entre um determinado sistema comunitário em que os hábitos refletem uma aproximação entre as pessoas, e uma formação social em que esses mesmos hábitos haviam existido em algum momento. Quero dizer, com isso, que é na experiência das antigas comunas medievais que Tocqueville vai se inspirar para racionalizar a imagem da democracia que vê na América (cf. Tocqueville, 1986, p. 61). Não é casual a comparação que faz, mais de uma vez, entre determinadas regiões dos Estados Unidos - notadamente a Nova Inglaterra - e Atenas do período clássico, onde o povo fazia as leis diretamente ou através de delegados em certas circunstâncias (cf. Tocqueville, 1986, p. 83).

Como se sabe, muitas cidades européias da fase medieval lembram, na sua estrutura básica, as cidades-Estado gregas. Mas há uma diferença essencial entre a longínqua pólis (ou mesmo as cidades medievais) e os novos centros urbanos que emergem na jovem república. O espírito público que predomina entre os anglo-americanos perde aos poucos o seu fundamento original e cede lugar a uma nova modalidade de ética que tem como base a "igualdade de condições", e cujo elemento primordial encontra-se no individualismo. Observa-se, mais enfaticamente, a tensão entre os dois modos de participação. Se Tocqueville surpreende-se com esse "inesperado retorno" à Antiguidade, não deixa de notar que o crescimento do individualismo e dos instrumentos de representação anulam, progressivamente, o espírito público do povo americano. O perigo que se avizinha pode até ser erradicado se o sistema mantiver seus traços "aristocráticos"; mas a situação é preocupante. Tocqueville possui relativa consciência tanto da inovação do novo arquétipo democrático quanto dos elementos antitéticos a ele intrínsecos. Isso o leva a compreender que "a força dos povos livres", que reside nas comunas, está ameaçada pelas "paixões passageiras, interesses de momento, (e) circunstâncias casuais". Afinal, o despotismo recalcado no interior da sociedade cedo ou tarde reaparecerá na superfície (cf. Tocqueville, 1986, p. 85) ${ }^{13}$.

Ao governo livre não acompanha o espírito da liberdade, porquanto os interesses pessoais sobrepõem-se ao interesse geral, concorrendo, assim, para a gestação de um regime em que os direitos da minoria discordante correm o risco de serem eliminados. Se antes o indivíduo desaparece na coletividade - como é o caso do passado clássico - agora a natureza do público é
13 Tocqueville nota perfeitamente uma forma de exercício de poder que começa a se extinguir progressivamente, cedendo lugar à representação, fruto da vitória (hamiltoniana) de um regime federativo sobre a democracia jeffersoniana. 
${ }^{14}$ Cf. a introdução de Lamberti ao L'ancien régime (Tocqueville, 1986, p. 903).

15 "Há mais de vinte anos que, falando de uma outra sociedade, escrevi quase textualmente o que se vai ler". Tocqueville escreve, em seguida, o que considera ser as "três verdades" responsáveis pelas "trevas do futuro" e que nada mais são do que os problemas levantados anteriormente, tais como a tirania da maioria, a irresistível força da democracia e a (lamentável) ausência de uma aristocracia capaz de amenizar "os efeitos perniciosos daquelas sociedades" (Tocqueville, 1986, p. 950-951). outra: a garantia do bem-estar pessoal. Assim, o interesse público consiste em assegurar, através de um consenso democrático, um governo que proteja o bem-estar material (cf. Tocqueville, 1986, p. 525). O bem público já não representa o mesmo papel que durante séculos fez a grandeza dos antigos, incluindo o sistema feudal anterior ao período que precedera imediatamente a Revolução Francesa. Mas esse bem público não se realiza sem uma certa ambigüidade; ou talvez seja mais adequado utilizar o termo dicotomia, porquanto ocorre em duas fases não totalmente opostas. Dessa maneira Tocqueville pode dizer que "um americano se ocupa dos interesses privados como se estivesse só no mundo e, um momento depois, entrega-se à coisa pública como se os tivesse esquecido" (Tocqueville, 1986, p. 525).

Percebe-se, pela aflição de Tocqueville, que o patriotismo americano deve-se aos próprios prazeres materiais, dos quais o Estado é o protetor. $\mathrm{O}$ bem público na democracia moderna está associado, portanto, ao que Tocqueville chama de individualismo (cf. Tocqueville, 1986, p. 496). Este é o grande problema (de origem democrática) que ameaça se desenvolver, uma vez que as condições se igualizam (cf. Tocqueville, 1986, p. 496). Isso difere essencialmente das sociedades aristocráticas, estáveis e hierárquicas que tornam, praticamente, "todas as gerações contemporâneas" (Tocqueville, 1986, p. 496), onde todos se conhecem e se ligam estreitamente. Para Tocqueville há uma impossibilidade congênita desse fato ocorrer nos Estados democráticos, já que o cidadão, individualmente mais fraco, é incapaz de preservar, isoladamente, sua liberdade. Sem os vínculos que o impelem a "unir-se aos seus semelhantes, para defendê-los, a tirania crescerá necessariamente com a igualdade" (Tocqueville, 1986, p. 501-502). É, pois, contra essa tendência - a possibilidade de um despotismo por parte das massas, sem qualquer espécie de controle-que Tocqueville consagra grande parte, senão a quase totalidade, de sua obra.

\section{Tirania da maioria: a ameaça do futuro}

É possível que nenhum outro texto de Tocqueville supere em fama o capítulo VII da segunda parte do primeiro livro de A democracia na Améri$c a$, justamente o trecho célebre em que ele, de forma quase profética, antecipa o que muitos neste século entenderam ser uma forma específica de totalitarismo. Contudo, esse capítulo é somente um item que se acrescenta à denúncia que Tocqueville faz dos perigos que podem incentivar o desinteresse pela forma política da liberdade. As preocupações que se manifestam n'A democracia estendem-se até $O$ antigo regime e a revolução, obra que Jean Claude Lamberti considera "uma verdadeira arqueologia do individualismo"14. Com efeito, desde o prefácio ao próprio corpo do livro, Tocqueville dá continuidade às análises que já lhe causavam incômodo duas décadas antes ${ }^{15}$. $\mathrm{O}$ individualismo, a democracia, a igualdade, e, conseqüentemente, os riscos que esta última traz - o despotismo das massas a que Tocqueville chama de tirania da maioria - são formas próprias do mundo moderno que, ao destruir a essência básica do espírito aristocrático, ameaçam a liberdade do cidadão e projetam 
sombras imprevisíveis sobre o futuro.

Adespeito do pessimismo contido, Tocqueville não se opõe ao avanço da democracia. No fundo persiste a esperança de que seus excessos podem ser amenizados por instituições que, nascidas do seio do novo regime, serão capazes de exercer um papel de relativa importância para conter aquele impulso desenfreado que emerge de uma multidão de seres uniformes e iguais. Tocqueville tem razões de sobra para não esperar mais do que a inclemente imposição da força da maioria sobre os exíguos direitos de uma minoria desprovida de quaisquer condições para lhe opor o mínimo esboço de resistência.

O temor da presença maciça e irresistível da opinião pública sobre o conjunto minoritário da sociedade incentiva-o a pesquisar os aparelhos adequados e eficazes que tenham chances de atenuar o progressivo poder ditatorial da maioria. Ao que parece, o receio de Tocqueville supera em muito suas expectativas. O impulso individualista não apenas se perpetua como os homens passam a ser cada vez mais uniformes e iguais - pelo menos no sentido em que Tocqueville atribui a esses dois conceitos. A uniformidade e a igualdade de oportunidades espalham-se por quase todo o mundo ocidental. A imagem de uma sociedade composta de indivíduos iguais em sua mediocridade ${ }^{16}$ choca-o na mesma proporção de sua admiração pelo regime democrático. Em que pese o conflito pessoal, ele declara sua preferência pelo sistema americano a qualquer outro. Presume-se que as vantagens políticas que se podem tirar do governo ${ }^{17}$ estão relacionadas aos instrumentos processuais das comunas da época feudal. Mas o invólucro individualista que reveste toda a vida diária do povo americano representa o prenúncio de um mal que pode facilitar o desenvolvimento do despotismo (cf. Tocqueville, 1986, p. 646). O isolamento individual, a ausência de virtude e dos laços hierárquicos, inerentes à antiga sociedade medieval, tornam os homens uma presa fácil das necessidades banais. Para desfrutá-las são obrigados a criar uma espécie de poder jamais visto na história da humanidade.

Estes indivíduos são, para Tocqueville, cidadãos atomizados, postos lado a lado por interesses privados e pessoais, que enxergam apenas a si mesmos. Em face a essa fraqueza, esses cidadãos fazem com que se erga, acima de todos, "um poder imenso e tutelar que se encarrega de assegurar-lhes os prazeres e de velar por sua sorte" (Tocqueville, 1986, p. 648). É sem dúvida esse poder, corporificado na opinião da maioria para a manutenção desses mesmos interesses pessoais, que, em circunstâncias particulares, tendem a tornar, na América, o poder da maioria não somente predominante, mas irresistível (cf. Tocqueville, 1986, p. 239). Naturalmente, Tocqueville não considera que a tirania seja um instrumento de uso freqüente; mas acredita que não há garantias contra ela (cf. Tocqueville, 1986, p. 244), porque a maioria possui um imenso poder de fato e um poder de opinião quase da mesma magnitude (Tocqueville, 1986, p. 240 e 244). Decerto não se equivoca ao detectar, na crescente força da opinião pública - o consenso democrático que sustenta e legitima a igualdade de condições e o individualismo do povo americano -, o germe do poder despótico de "novo tipo" que se apodera da sociedade: a tirania da maioria. Atento para o mal generalizado que se oculta sob essa onipotência, julga ser quase impossível
${ }^{16}$ A palavra médiocre, traduzida muitas vezes (erroneamente) como medíocre, tem, na língua francesa, um sentido diferente daquele que possui no idioma português. Enquanto a língua portuguesa atribui ao termo uma conotação pejorativa, no idioma gálico ele se refere, antes de mais nada, a um estado de coisas que torna tudo igual e mediano. Mas a ênfase que Tocqueville dá ao conceito de igualdade como algo qualitativamente inferior ao passado aristocrático termina por conceder à expressão um sentido mais negativo do que sua significação literal.

17 "As vantagens políticas que os americanos retiram do sistema de descentralização me fazem preferi-lo ao sistema contrário" (Tocqueville, 1986, p. 112). 
18 Para Tocqueville, o "espírito democrático" pode fazer maravilhas, mas não produzirá mais que um governo sem virtude e sem grandeza, pois cada um de seus membros está preocupado mais com seus assuntos privados do que com as questões públicas; mais com seus interesses pessoais do que a grandeza da nação (cf. Souvenirs, em Tocqueville, 1986, p. 730).

19 Termo utilizado por Werneck Vianna para expressar o sentido que Tocqueville imprime ao conceito de "nova aristocracia". Para o ideal de liberdade fundado nesses princípios cf. Vianna (1993). recorrer contra os "abusos" da opinião pública:

"Quando um homem sofre uma injustiça nos Estados Unidos, a quem poderia dirigir-se? À opinião pública? É quem forma a maioria; ao corpo legislativo? Representa a maioria e lhe obedece cegamente; ao poder executivo? É nomeado pela maioria e lhe serve de instrumento passivo (...) os próprios juízes, em alguns Estados, são eleitos pela maioria" (Tocqueville, 1986, p. 244).

Uma vez que a força desse poder reside mais nos costumes do que nas leis, é provavelmente no espírito legista que a liberdade pode encontrar meios de se contrapor aos desvios provocados pela democracia ${ }^{18}$. Os homens que se dedicam ao estudo das leis criam "um amor instintivo pelo encadeamento regular das idéias que os torna, naturalmente, fortes opositores do espírito revolucionário e das paixões irrefletidas da democracia” (Tocqueville, 1986, p. 253). Parece haver, nesse raciocínio, uma séria contradição entre os princípios legais que determinam os limites da democracia, e os princípios éticos que alimentam a força da maioria - costumes, hábitos -, porquanto Tocqueville afirma, anteriormente, que a natureza impositiva da opinião pública envolve o próprio judiciário por meio das eleições. A impressão que se tem das palavras de Tocqueville é que no fundo prevalece mais uma posição de status dos membros do judiciário do que a idéia de lei em si. Com efeito, Tocqueville percebe na instituição do tribunal - com seus advogados, juízes, homens de lei, em geral - um órgão cujas funções assemelham-se àquelas exercidas pela aristocracia no regime feudal.

Por se encontrar no fundo da alma dos legistas hábitos aristocráticos e desprezo pelo governo do povo (Tocqueville, 1986, p. 253 e 257), o tribunal, como uma espécie de aristocracia americana, é a instância ideal capaz de evitar que o povo agrida seus princípios. Existe aqui uma espécie de antagonismo no raciocínio de Tocqueville que fere a lógica do seu argumento. Como poderá essa instituição salvaguardar os direitos da minoria se ela própria é dominada pelo sentimento de unanimidade que preside o espírito americano? Não lamenta Tocqueville o fato de que dificilmente um homem injustiçado pode se dirigir a qualquer instância para fazer valer suas reivindicações, à medida que os próprios juízes estão submetidos à lógica do pensamento único? Em defesa de Tocqueville poderíamos dizer que sua teoria política não se detém na análise da magistratura como único meio de obter garantias contra o abuso de poder. No capítulo VII da quarta e última parte de A democracia na América, nosso autor retoma o problema dos corpos intermediários reconhecendo que existem outros loci que exprimem, analogamente, o espírito aristocrático da sociedade. A despeito de não acreditar na fundação de uma nova aristocracia no mundo, seu "correlato funcional" 19 está presente na forma de associação de cidadãos que, "ao defender seus direitos particulares contra as exigências do poder, salva as liberdades comuns" (Tocqueville, 1986, p. 652).

Tocqueville está correto em apontar esses agrupamentos da sociedade civil como um sério empecilho ao abuso de poder por parte da maioria. 
Seu erro, porém, consiste em subestimar a capacidade regeneradora do individualismo democrático que atua sempre como antítese aos seus supostos princípios. Chancellor Kent, por exemplo, admite, em 1821, que "a tendência do sufrágio universal é de pôr em risco o direito de propriedade e os princípios da liberdade" (Apud Dahl, 1990, p. 59) ${ }^{20}$. Lembraria, aqui, o ensaio, de certo modo pioneiro, de Adam Przeworski, que sustenta ser o projeto neoliberal uma tentativa da burguesia recuperar sua revolução, interrompida com o advento da democracia e do sufrágio universal (cf. Przeworski, 1989, p. 258). A retomada do projeto original não elimina, no entanto, a validade das análises do pensador francês; ao contrário, confirma seus temores e em níveis que ele jamais poderia imaginar. As associações, fragmentadas pelo isolamento cada vez maior dos indivíduos, ao invés de agirem como uma espécie de aristocracia na proteção da liberdade do sujeito subordinam-se, igualmente, aos indivíduos atomizados, à ditadura da maioria.

O conformismo generalizado e uma cultura do contentamento tiranizam a vida social, econômica, política e mesmo intelectual das sociedades pós-modernas. Não é sem razão que um conhecido analista da história dos Estados Unidos aponta para as tendências absolutistas da política norte-americana. Para ele, o problema, porém, é que no nosso século o despotismo não reside apenas na inclinação das posições majoritárias que dominam essa sociedade. A questão essencial é que o fato dessa nação representar o mecanismo liberal da Europa posto a funcionar sem o antagonismo social europeu não houve uma classe a qual destruir - terminou por contribuir para a formação, no interior do país, de uma espécie quase absoluta de unanimidade (cf. Hartz, 1955, p. 11 e 16). Não há espaço, portanto, para se pensar uma reação das minorias como oposição ao despotismo majoritário. Todo esse problema deve-se, talvez, à concepção de democracia nos escritos de Tocqueville.

Tentei explicar, sumariamente, um pouco mais acima, o seu conceito de democracia. Laski já notara, há tempos, um mal-entendido no significado de igualdade em pensadores liberais tais como Tocqueville (cf. Laski, Grammar of politics, apud Dahrendorf, 1981, p. 242). De fato, Tocqueville atribui à democracia apenas uma igualdade formal, de condições, muito embora ele devesse ter consciência de outras formas de representação igualitária, uma vez que se refere a diferentes modelos em seu discurso na Assembléia Constituinte em 1848. Mesmo assim ele não leva em consideração a possibilidade de expansão da igualdade na sua variante socialista. E a razão mais plausível para esse "descuido" é a relutância de Tocqueville em dar atenção à igualdade econômica, preferindo ater-se ao conceito restritivo de igualdade liberal de condições.

A ausência de reconhecimento de que outra espécie de igualdade possa expandir-se por todo o mundo obscurece, em parte, o seu pensamento. Esse fato se deve, provavelmente, à força predominante da democracia liberal à época; o que explica porque Tocqueville vai buscar sua idéia onde a vê "ativa, triunfante, no único país do mundo onde realmente existe, onde se fundou, no mundo moderno, algo grande e duradouro: na América do Norte" (Tocqueville, 1988, p. 160). Este, porém, não é o único motivo pelo qual

\footnotetext{
${ }^{20}$ Para esta questão cf. Magalhães (1993, p. 31-32).
} 
${ }^{22}$ A rigor Tocqueville atribui essa limitação a toda sociedade de caráter coletivizante. No entanto, em função das várias teorias socialistas a respeito da liberdade individual do cidadão, é discutível essa generalização que ele faz sobre as formações sociais não liberais.

23 Jamais devemos esquecer que na Introdução de $A$ democracia na América Tocqueville propõe uma nova ciência política para um novo mundo (Tocqueville, 1986, p. 44).

${ }^{24}$ Refiro-me aos dispositivos da democracia formal, a exemplo do sufrágio universal, que foram mantidos pelos comunards durante todo o período embora efêmero - que durou a Comuna.
Tocqueville se recusa a aceitar que a democracia possua outras determinações que não a mera igualdade de oportunidades. Sua rejeição à revolução social leva-o a confundir sistemas econômico-políticos com formas de governo. À democracia liberal opõe o socialismo, e a este a liberdade e não o capitalismo (cf. Tocqueville, 1988, p. 160-162).

Independentemente do seu aguçado senso político, que antecipa a limitação da esfera da autonomia individual em determinados sistemas socialis$\operatorname{tas}^{22}$, Tocqueville permanece confinado a uma concepção de democracia que despreza, em geral, qualquer forma mais íntima de igualdade econômica. Ao afirmar que a "República de fevereiro deve ser democrática, mas não socialista" (Tocqueville, 1988, p. 162), ele contrapõe categorias correlatas a conceitos diferenciados. Sempre é possível afirmar que o sociólogo estuda uma tendência dominante no século XIX, e que escapar aos fatos concretos é substituir o que é pelo que deveria ser. Mas ao cientista político não é desculpável omitir projeções futuras a partir de acontecimentos observáveis e passíveis de realização a longo prazo $^{23}$. Coisa que, de resto, ele próprio o fez em determinado momento.

O chamado "espírito da época" - isto é, o contexto sociopolítico e as idéias sob as quais se vive - possui elementos demasiadamente fortes para que alguém possa, de certo modo, deixar de submeter-se aos seus desígnios. Mas ao observador atento não é dado o direito de negligenciar o conhecimento das forças "latentes ou subalternas" de uma sociedade que se contrapõem à ideologia dominante. O movimento operário de 1871, por exemplo, demonstra, embora por pouco tempo, que a democracia pode se conciliar com o regime socialista ${ }^{24}$. A guerra civil na França, de Marx, testemunha todo o processo político democrático que se desenvolve durante três meses na Comuna de Paris. Assim, a falta de uma maior precisão do conteúdo real do significado que Tocqueville empresta à palavra democracia, e não obstante suas advertências para esse tipo específico de sociedade, traz profundas implicações para que essa concepção moderna de democracia seja devidamente avaliada. É por limitar-se a esse conceito restrito de democracia, que a maioria dos liberais - e mesmo da esquerda - encontra-se diante do falso dilema de escolher uma opção entre liberdade e igualdade.

No entanto, as preocupações de Tocqueville incomodam, ainda nos dias de hoje, liberais de todos os matizes e amplos setores da esquerda que, sem uma resposta justificável para a difícil relação entre liberdade e democracia, assiste, atônita, à gradativa redução desta última sem que com isso aumente a participação das massas nos processos de decisão política. Em princípio, e da forma seca como aqui se apresenta, esse enunciado pode sugerir, ao olhar menos atento, uma afirmação vaga e apressada do momento, ou mesmo em desacordo com o sentido de democracia pensado por Tocqueville. Mas essa leitura só é possível se nos ativermos exclusivamente ao tipo de democracia que se esboça no século XIX.

A época em que vivemos exige um outro entendimento do problema, principalmente porque é preciso investigar até que ponto e em que medida é possível reconhecer a validade do pensamento de Tocqueville. Portanto, o enun- 
ciado acima pode ser encarado como correto se entendemos a democracia segundo novos paradigmas. As questões levantadas pela modernidade - liberdade, igualdade, consenso, democracia etc. - não só permanecem indefinidas como eivadas de grandes interrogações. Os conceitos de democracia e liberdade jamais foram fixados com precisão; estão sujeitos a definições variadas e são interpretados segundo a leitura e o entendimento do mais heterogêneo grupo de autores ${ }^{25}$. Marx diz que "a democracia é o enigma resolvido de todas as constituições". E talvez, por ser um enigma, sustenta Marilena Chauí, é que ela pode tornar-se um vasto campo de interrogação. Assim, a democracia é capaz de abranger um arco que abriga um misto de princípios, instituições e métodos, entendidos estes últimos como vinculados à necessária mutação histórica que sofrem com o tempo (cf. Chauí, 1997, p. 137-162). Também para Touraine, a democracia nãoé um objeto simples. Ela não é apenas um conjunto de garantias institucionais. Consiste, igualmente, na luta de sujeitos impregnados de sua cultura contra o que ele chama de "a lógica dominadora dos sistemas" (Touraine, 1996, p. 24). A democracia, para ele, não existe sem a igualdade política, mas não se resume a isso, e não satisfaz se não há meios de compensar as desigualdades que não se vinculam meramente ao formalismo jurídico (cf. Touraine, 1996, p. 37). A democracia configura-se, portanto, como um "crescente poder social sobre a personalidade e a cultura", razão pela qual o "caráter próprio da sociedade moderna é essa afirmação da liberdade que se exprime, antes de tudo, pela resistência a [esse] domínio" social (cf. Touraine, 1996, p. 24) ${ }^{26}$.

Fugiria ao tema, porém, se ampliasse o debate sobre a democracia e a liberdade, notadamente porque existem inúmeras tendências e escolas políticas que possuem uma forma particular de enfrentar o assunto. No entanto, é impossível furtar-me inteiramente a abordar a questão à medida que a idéia central deste trabalho exige uma compreensão desses conceitos à luz da nossa contemporaneidade. Se não entendo a democracia como elemento puramente procedural, - tenho em vista também um elenco de fatores presidido, inclusive, pelo critério de valores (digamos, sociais, por exemplo) -, não posso deixar de reconhecer que ela é também um método, um modo pelo qual o poder é exercido. Todavia, é o conteúdo objetivo e concreto - sua normatização - que vai conferir força e vitalidade à sua conceituação.

Assim, se entendemos a democracia de acordo com o exposto acima, é fácil perceber que o padrão estabelecido pelas sociedades liberais de hoje para compor seus mecanismos de decisão permite que se interprete a política democrática do liberalismo atual - tanto quanto a de Tocqueville como amplamente reducionista. Esses fatos foram vivamente demonstrados pelo estudo já citado, de Adam Przeworski, sobre o capitalismo nesse final de século. $\mathrm{O}$ cientista político polonês descreve criticamente as tendências do pensamento liberal contemporâneo como preocupado em desmantelar as organizações trabalhistas e promover a sobrevivência apenas dos mais aptos, os que estão integrados no mercado (cf. Przeworski, 1989, p. 258-259).

Com efeito, o projeto de desregulamentação da economia e das relações de trabalho, que se convencionou chamar de neoliberal, vale-se dos argu-
${ }^{25}$ Liberdade e Igualdade não são termos genéricos que possam ser usados por todos num único sentido. Eles variam a partir da pergunta para que e para quem servem a liberdade e a igualdade. Nesse aspecto, a democracia admite, do mesmo modo, diversos significados se vistos sob a ótica de quem formula o seu conceito. Há, porém, uma espécie de consenso em torno de um dos seus objetos. A corrente que se convencionou histórica e tradicionalmente chamar de direita tende a excluir do conceito de democracia o seu conteúdo social (ou, ao menos, trata-o com certo desprezo), privilegiando as regras formais e seu desenvolvimento puramente procedural. Sobre a relação entre as duas categorias iniciais aqui discutidas, cf. o artigo de Célia Galvão Quirino (1983, p. 107).

${ }^{26}$ Grifo no original. 
${ }^{27}$ Essa não é, aliás, uma idéia nova. Ela pertence à concepção liberal da democracia desde seus primórdios. Em que pese a diferença terminológica em relação à época, o sentido geral do seu ideário permanece essencialmente $o$ mesmo. Se hoje a expressão predominante é mercado, no século XIX, por exemplo, era propriedade. Contudo, a noção de que apenas aqueles que fazem parte desse universo são sujeitos políticos em nada se modifica. $\mathrm{O}$ cidadão do século passado é quem possui tempo e lazer, e, portanto, quem tem posses. Neste final de século, embora a cidadania seja extensiva a todos - pelo menos formalmente - é difícil considerar o indivíduo que se encontra à margem do sistema de mercado - desempregado e sem perspectiva - um cidadão. Sobre a relação cidadão/ propriedade ver o ensaio de Benjamin Constant, Principes de politique, especialmente o capítulo VI, Des conditions de proprieté (Constant, 1980, p. 315-324). mentos teóricos e instrumentos práticos para tentar demonstrar a inviabilidade das decisões tomadas diretamente pela população (a exigüidade de tempo, a legitimidade da representação etc.). Nesse aspecto pode-se dizer, se bem interpreto o pensamento de Przeworski, que o objetivo primordial da liberdade moderna é a liberdade de mercado, ou seja, tenta-se privilegiar os agentes que nele estão integrados ${ }^{27}$. O resultado é uma incrível semelhança política e econômica com as aspirações da burguesia do século passado, bem como uma retomada do próprio estatuto político da cidadania da primeira vaga liberal. Em outras palavras: o direito do cidadão resume-se a uma participação no trabalho sem qualquer acesso ao processo decisório direto, processo este extensivo apenas àqueles que controlam o sistema produtivo ou seus delegados (representantes). A participação restringe-se a grupos específicos de composição qualitativa, isto é, a uma selecionada camada que decide, através dos instrumentos fornecidos pelo mercado, quais os direitos e os deveres dos cidadãos. Esse fenômeno apresenta uma contradição que não é visível aos olhos de Tocqueville. Embora o instituto da representação já seja dominante na primeira metade do século XIX, os elementos de democracia direta exercem, ainda, um importante papel na vida dos americanos. Tocqueville pode sentir o peso da maioria sem notar que as decisões pertencem, efetivamente, a uns poucos. A democracia direta existe, é verdade, mas cede, cada vez mais, terreno ao sistema representativo. Esta é, contudo, uma contradição aparente, uma aporia, uma vez que, mesmo indiretamente, essas decisões terminam por serem sufragadas pela maioria. Esse mecanismo produz um duplo movimento: oferece a impressão de que a maioria realmente decide, gerando uma aceitação passiva da comunidade, e faz avolumar a apatia eleitoral e o desinteresse pela coisa pública.

Trata-se de um ideário que parece retroagir à fase anterior ao Estado do Bem-Estar Social, em que a organização política é, na expressão de Marx, apenas um "comitê executivo dos negócios da burguesia". Na experiência prática, porém, persiste a estrutura formal da representação, em que um conjunto supostamente majoritário da sociedade decide por meio do sufrágio universal. Contudo, para a democracia moderna importa menos a forma de seu exercício do que o "espírito" que nela radica. De um modo ou de outro uma opinião geral prevalece, abolindo quase que por inteiro as vozes dissidentes. É em socorro dessa minoria impotente diante do clamor ensurdecedor das "multidões opressoras" que Tocqueville dirige seus apelos. Apelos que se materializam numa aristocracia moderna, particularmente no espírito jurista.

Esse espírito legista, todavia, não é suficiente para obstar o enorme risco que corre a democracia americana, à medida que se torna vítima do próprio princípio básico que nutre a ideologia da mentalidade americana: o consenso absoluto. À época de Tocqueville - e de alguma maneira também em nossa era -, essa absolutização do pensamento viola frontalmente os direitos da minoria que não possui outra forma de expressar o seu descontentamento que não seja por meio da violência. Assim, o poder da maioria tende a entrar em choque com uma instituição que, no futuro, implicará em resultados profundamente dramáticos para essa sociedade - a escravidão. A presença do negro em solo america- 
no, após a abolição da escravatura, é "o mais temível de todos os males que ameaçam o futuro dos Estados Unidos" (Tocqueville, 1986, p. 317). Tocqueville explica essa ameaça pela própria forma moderna segundo a qual a escravatura foi implantada. A libertação dos escravos traz, na própria natureza histórica, graves e profundos problemas para os destinos da América. Por um lado, diz, a abolição da escravidão não se opera em benefício dos negros, mas nos interesses dos próprios brancos, pois se a servidão é cruel para o escravo, não deixa de ser funesta para o senhor. Afinal, é muito menos dispendioso pagar salário ao operário livre do que arcar com as despesas da manutenção do escravo (cf. Tocqueville, 1986, p. 320-322). Por outro, o novo modelo de escravidão tem sua origem em povos de raças diferenciadas. Para os antigos, o escravo pertence à mesma raça que o senhor e não é raro que aquele possua educação superior a este último. Tocqueville menciona, inclusive, os casos clássicos de Esopo e Terêncio (cf. Tocqueville, 1986, p. 317). Assim, "apenas a liberdade os separava", e os "traços da escravidão não subsistiam muito tempo depois que a servidão era destruída" (Tocqueville, 1986, p. 317).

A instituição da escravatura negra alicerça-se sobre outras bases. $\mathrm{O}$ escravo moderno não se diferencia do senhor apenas pela liberdade, mas pela própria origem. Ao se tornar livre, o negro permanece, diante do europeu, na condição de um estranho. Por isso, os modernos precisam destruir ainda os preconceitos do senhor, da raça e do branco (cf. Tocqueville, 1986, p. 317). A liberdade torna-se puramente formal, uma vez que o escravo livre encontra toda sorte de obstáculos no seu caminho em direção à emancipação. A lei permite ao ex-escravo todos os direitos; mas a cidadania, na política, lhe é

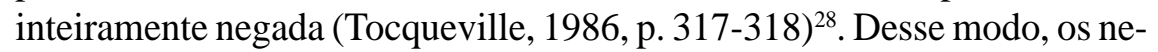
gros libertos, mas sem qualquer chance de assumir um lugar no seio de uma sociedade preconceituosa, encontram-se em meio a uma nação de brancos iguais. As consequiências dessas limitações se farão sentir tanto no século XIX quanto no século seguinte, onde a "maioria" de iguais exerce seu despotismo sobre os sobreviventes da democracia individualista.

\section{A cultura do contentamento - profecia realizada?}

Um século e meio medem a distância da nossa época daquela em que Tocqueville diagnostica os traços mais gerais de uma sociedade de tipo novo em formação. Nela, a tendência para a igualdade é irreversível. Tocqueville pode pensar dessa maneira porque se encontra diante de uma sociedade cujas condições, naquele tempo, são "historicamente excepcionais" devido a uma "vasta reserva de terras" (Dahl, 1990, p. 63). Mas a sorte americana termina com a nova ordem capitalista de pessoas jurídicas (cf. Dahl, 1990, p. 63). "O capitalismo das sociedades anônimas - escreve Dahl - geraria automaticamente desigualdades na distribuição da propriedade, bem como em outros recursos sociais e econômicos (... ). O homem tornou-se o homem econômico, a democracia foi identificada com capitalismo, a liberdade com a propriedade e seu uso, a igualdade com oportunidade de ganho, e progresso
${ }^{28}$ Tocqueville cita, num estilo admirável, a objeção que a sociedade branca impõe aos negros, apesar da igualdade legal concedida aos escravos após a abolição. 
${ }^{29}$ Embora não se possa levar a idéia muito longe, é passível de especulação o comportamento de Tocqueville diante dos acontecimentos de 1848 , quando teme pela segurança da propriedade frente à possibilidade de um governo socialista (cf. Tocqueville, 1988, p. 152 e 157).

${ }^{30}$ Reforça a linha de argumento aqui apresentada a opinião de Lefort, para quem "nada autoriza, pois, a deduzir da igualdade de condições uma igualdade em todos os pontos" (Lefort, 1991, p. 222).

31 Este é um problema que pode ser extensivo a outros tipos de minoria. com mudança econômica e acumulação de capital” (Dahl, 1990, p. 63-64). A propriedade torna-se mais complexa e contribui para aumentar o abismo entre a expansão das grandes corporações e a "oportunidade de igualdade" dos indivíduos isoladamente. Tocqueville não tem a chance de ver a mudança de rumo que sofre a "igualdade de condições" da democracia americana, nem o novo padrão de relações de propriedade. Mesmo assim não acredito que esse fato tenha grande importância para ele, a não ser pelas consequiências que poderiam advir da transformação qualitativa do regime de propriedade, particularmente no que se refere aos meios de decisão.

A mudança não causa qualquer ameaça ao direito de propriedade; apenas concentra-se em um número mais reduzido de mãos. Mas se de um lado modifica-se o sistema jurídico da propriedade, nada altera o regime individualista sobre o qual Tocqueville elabora a sua teoria. Por outro lado, em face à ausência de uma ameaça mais grave ao estatuto jurídico-político da propriedade, o aristocrata francês, diferentemente dos demais liberais de então, não concede muita atenção a esta questão, exceto em algumas poucas páginas e sem grande destaque ${ }^{29}$. De qualquer forma, não creio que passados esses cento e cinquienta anos sua teoria tenha perdido a validade no tocante às preocupações com o problema da liberdade e às possíveis ameaças a ela dirigidas pelos excessos individualistas do regime democrático. Mas é preciso que se leve em consideração - repito mais uma vez - que a igualdade da qual fala Tocqueville não é a igualdade de bens, e sim a igualdade de condições. Ele mesmo chega a mencionar que não conhece um país "onde se professe um desprezo mais profundo pela teoria da igualdade permanente de bens" (Tocqueville, 1986, p. 79) ${ }^{30}$.

Esse problema não é de pouca importância, porque se refere exclusivamente às formações sociais em que a idéia de democracia está associada a conceito de individualismo e à concepção burguesa de sociedade. E o conceito de democracia em Tocqueville encontra-se vinculado, diretamente, à construção originária dessa mesma sociedade. Os riscos e ameaças provenientes dessa espécie de regime ocorrem em função de interesses bem particulares, em que o problema da liberdade só pode ser visto se analisado sob esse prisma. A ameaça que paira ainda hoje sobre as minorias é a consequiência lógica de uma estrutura social que tem o seu desenvolvimento instituído através da opressão de camadas minoritárias, principalmente o segmento negro que permanece à margem de todo progresso material. Os distúrbios de abril de 1992, em Los Angeles, não atestam somente uma exclusão dos frutos do progresso democrático; eles se reafirmam, lamentavelmente, como um produto tardio das advertências de Tocqueville ao processo de discriminação sofrido pelos negros depois da abolição. A segregação racial levará os negros à indignação ao se verem privados dos seus direitos e estes não tardarão a se mostrar inimigos de uma sociedade racista (Tocqueville, 1986, p. 333) (1) $^{31}$

A tirania da maioria, o grande temor de Tocqueville, estende seu poder em tal dimensão para os dias atuais, que oprime de maneira violenta, embora diferenciada, negros e brancos. O receio de Tocqueville confirma-se de modo aterrador, o que leva John Kenneth Galbraith a denominar a tirania 
neoconformista de Ditadura dos ricos ou de Cultura do contentamento. Vivese, hoje, na América, o pesadelo de uma "ditadura da classe satisfeita" (Galbraith, 1992a, p. 63). Nos Estados Unidos, essa classe - isto é, o conjunto formado pelos ricos, pela classe média e pelos estratos em ascensão -, aquela que recebe os benefícios do bem-estar material, torna-se satisfeita porque é maioria $^{32}$. Isso não significa que a subclasse, aquela composta pelos descontentes e que forma a minoria americana, não tenha as suas garantias. A democracia da "classe eleitoralmente satisfeita" atinge todos indistintamente, ainda que o dissenso permitido seja "formal" (cf. Galbraith, 1992a, p. 63). Não é de estranhar que a prosperidade, o sonho de toda sociedade, chegue de uma forma que produza violência (cf. Galbraith, 1992a, p. 63). Isso se deve, de certo modo, ao conformismo já notado por Tocqueville, mas que se eleva a um grau sem precedentes na história dos Estados Unidos.

Os beneficiários do sistema preferem optar pelo que se convencionou chamar de inação a curto prazo - ainda que diante dos grandes males sociais - ao invés da ação benéfica num período mais dilatado mas que resulte em novos encargos para a maioria satisfeita (cf. Galbraith, 1992a, p. 65). As revoltas sociais são o preço a pagar pela aceitação do imobilismo. Galbraith acentua o medo existente entre aqueles que de alguma maneira pretendem fazer grandes reformas, de levar ao conhecimento da classe satisfeita que mudar tem seus custos (cf. Galbraith, 1992a, p. 67). Esse princípio foi muito bem compreendido por aquele que, como Tocqueville, tem a pretensão de, a partir de fatos recentes da história política mundial ${ }^{33}$, explicar a irresistível força da democracia liberal como fenômeno inevitável e irreversível.

Dotado de um certo talento para a percepção da realidade, ainda que sem o brilho do pensador francês, Fukuyama reconhece que "todo esforço para dar aos desprivilegiados uma dignidade igual significará o cerceamento da liberdade ou direitos de outras pessoas" (Fukuyama, 1992, p. 292 293). Mas termina por aceitar a condição do despotismo majoritário ao concordar com a inevitável diferença entre ricos e pobres, e de condenar o projeto igualitarista de uma sociedade mais justa, pois "cada dólar gasto pelo governo com o seguro nacional de saúde ou com o bem-estar social significa menos investimento para a economia privada; cada tentativa de proteger os trabalhadores contra o desemprego ou as firmas da falência significará menos liberdade econômica" (Fukuyama, 1992, p. 292) 34. $^{34}$.

Contudo, Fukuyama provavelmente tem razão quando faz a crítica à forma extrema pela qual a igualdade social eliminou a liberdade nos países ditos socialistas. Destarte, seu horizonte limitado enxerga a sociedade democrática liberal não em termos simétricos aos de Tocqueville, mas sobre o mesmo tema argumenta em favor da desigualdade, mesmo que sua meta seja, aparentemente, a isothymia. Essa idéia de desigualdade natural é, aliás, uma tese comum a todo pensamento liberal ${ }^{35}$. Não surpreende que a igualdade de capacidade termine por impor a força do talento que, em outros termos, nada mais representa que a força do privilégio, seja qual for o significado que se aplique a essa palavra. Compreende-se que, frente à limitação do acesso a
32 "No passado, isso está claro, as pessoas bem de vida e satisfeitas consigo próprias constituíam uma pequena minoria (...) de fora ficava a maioria dos cidadãos. Hoje nos Estados Unidos esses favorecidos são numerosos, influentes e a maioria dos eleitores". Veja-se que Galbraith não fala da maioria da população, mas dos "eleitores" (cf. Galbraith, 1992b, p. 89) (Destaque meu).

${ }^{33}$ Refiro-me a Fukuyama (1992) que, ao contrário de Tocqueville (mas seguindo suas pegadas no que diz respeito ao exame da democracia), não promove um estudo detalhado dos fatos, ou seja, teoriza sobre a validade dessa forma de governo por meio de um "empirismo estreito" ou de observações de curto alcance.

${ }^{34}$ A excessiva defesa do mercado separa, aqui, o autor nipo-americano de Tocqueville. O sociólogo francês, mesmo com sua postura anti-socialista, não vai tão longe. Em 1848 , em meio ao tumultuado cenário parisiense, propõe uma série de reformas em benefício do povo, ressaltando a necessidade de criar instituições para o combate à pobreza, inclusive o estabelecimento de escolas gratuitas, redução da jornada de trabalho e fundos de ajuda mútua (cf. Jardin, 1988, p. 322). 
bens materiais apenas aos mais capazes - como se a seleção natural alcançasse a qualidade de seleção social -, a minoria reprimida, constituída predominantemente por grupos negros ou de origem hispânica (cf. Galbraith, 1992b, p. 19), busque o exercício dos seus direitos por intermédio de instrumentos extralegais, ou seja, por meio da violência.

A tranqüilidade "é algo com que ninguém deve contar no futuro", sustenta Galbraith (1992b, p. 19). A revolta de Los Angeles (que em certo sentido atingiu outras cidades, como Atlanta, cujo saldo foi de 58 mortes - em menor escala seus reflexos também alcançaram a cidade de Nova York) pode parecer um episódio isolado em meio à "prosperidade" na afluente sociedade americana. Mas será casual o fato de que esta "modesta" rebelião tenha sua origem em setores minoritários americanos, notadamente naqueles compostos por negros? Obviamente, ninguém de bom senso prevê, hoje, qualquer forma de explosão revolucionária nos Estados Unidos. Mas nas advertências de Galbraith parecem ecoar os temores de Tocqueville num passado nem tão distante assim:

"Se a América experimentar alguma vez grandes revoluções, elas serão conduzidas pela presença dos negros no solo dos Estados Unidos: quer dizer, não será a igualdade, mas ao contrário, sua desigualdade que as fará emergir" (Tocqueville, 1986, p. 604).

Como é possível observar, a igualdade de condições conduz a um equilíbrio do bem-estar entre os iguais, permanecendo de fora das vantagens materiais produzidas pela democracia importantes camadas sociais, cujo acesso aos prazeres e comodidades da vida moderna lhes é inteiramente negado.

\section{A indagação final}

Tocqueville tem razão ao descrever os sintomas da doença que pode contagiar todo o organismo social caso não seja encontrado o remédio adequado para impedir seu alastramento. Existe, porém, em suas análises, um duplo equívoco que deixa em aberto as respostas para a cura dos males provocados pela disseminação do processo democrático. O primeiro deles é de natureza conceitual. Tocqueville concede uma abrangência demasiadamente vasta ao processo democrático no que tange a sua universalidade, mas limita-o ao modelo individualista. Não obstante fosse quase impossível conhecer a teoria marxista que come-

${ }^{35}$ Ao igualitarismo interessa apenas que todos sejam iguais (...) independentemente da capacidade; aos defensores da igualdade na liberdade ocorre o inverso, interessa uma real possibilidade de uma pluralidade de escolha..." (Matteucci, 1981, p. 62) (Grifo meu). çava a surgir à época - o conhecimento das teorias de Marx não se dá antes de 1848, quando muito - Tocqueville claramente não desconhece as concepções socialistas que têm em mente um modelo diferente da sociedade individualista que está a sua frente. Mas são sobretudo projetos ideais que não correspondem ao que ele vê na prática. Provavelmente, muitos negarão a importância desses fatos sob o argumento de que, se a democracia é um valor universal, a igualdade que a acompanha e lhe serve de suporte também deve-se incluir nesse conjunto, o que em outros termos resulta numa igualdade universal.

A universalidade democrática, porém, refere-se aos seus mecanismos formais, isto é, ao exercício do poder enquanto tal, em si mesmo. Já o 
conceito de igualdade, como diz Bobbio, é sempre relativo e diz respeito aos sujeitos entre os quais se propõe repartir os bens, quais os bens a repartir e quais os critérios de repartição. "Os sujeitos podem ser todos, muitos ou poucos, ou ainda um só; os critérios podem ser o mérito, a necessidade, o trabalho, o lugar" (Bobbio, 1994, p. 73). Com toda certeza, o problema dos bens e da necessidade não se encontra nas avaliações de Tocqueville e dos liberais como um todo. A igualdade de que falam - e Tocqueville em especial - tem um cunho específico que envolve a questão da individualidade, mas que foi universalizada. Uma democracia pode oferecer a todos oportunidades iguais. Mas os benefícios só podem ser auferidos por todos aqueles que são iguais. Sem justiça social para repartir os bens com relativa eqüidade qualquer valor universal de uma democracia permanecerá sempre excludente.

É, todavia, no antídoto aos excessos da democracia, e aqui encontrase o centro do segundo equívoco, que Tocqueville deixa o problema sem solução. Sua identificação instintiva com a classe a que se encontra vinculado por nascimento ${ }^{36}$, impele-o a ver, apenas na aristocracia, ou melhor, nas funções análogas a ela (o Judiciário, por exemplo), o elemento moderador do ímpeto despótico. Sem dúvida, Tocqueville compreende a importância da liberdade como ferramenta política capaz de se opor à tirania da maioria. Mas o aspecto formal do "espírito" aristocrático não pode ser admitido, na teoria de Tocqueville, sem a conseqüente ligação com o seu correspondente conteúdo. A evolução da democracia individualista confirma os prognósticos tocquevilleanos a respeito da universalização de um tipo particular de pensamento, mas o remédio é ineficaz. O espírito legista representa o espírito da mentalidade individualista e o peso da opinião da maioria interfere no julgamento daqueles que, em princípio, deveriam ser surdos às exigências majoritárias ${ }^{37}$.

Tocqueville percebe o pouco interesse dos americanos para a política. Alienados da coisa pública, provavelmente seriam incapazes para eleger bons representantes (cf. Jasmin, 1991, p. 49). O que Tocqueville não vê - ou melhor, vê mas não consegue se desvencilhar da armadilha de seu próprio argumento - é a impossibilidade de uma aristocracia influenciada pelo pensamento único criar seu próprio espaço para a liberdade. Já que na América "a maioria traça um círculo formidável em torno do pensamento" (Tocqueville, 1986, p. 245), impedindo o indivíduo de ultrapassar os "limites" da liberdade - Tocqueville fala especificamente do escritor, mas estende seu raciocínio à liberdade de opinião em geral -, como acreditar que os juristas estão isentos dessa influência? O legista "age sem cessar" sobre o poder dessa opinião, mas o corpo de juristas é uma força que poucos temem e que se "curva com flexibilidade às exigências de tudo e se deixa levar sem resistência a todos os movimentos do corpo social" (Tocqueville, 1986, p. 258).

Não seriam inócuas, portanto, essas tendências aristocráticas à medida que exigem a presença de valores cujas condições de concretização são destruídas pela experiência da modernidade $?^{38} \mathrm{O}$ amplo domínio de uma forma específica de pensamento (e comportamento) enfraquece os espíritos, torna os indivíduos insatisfeitos e "incapazes de formular alternativas própri-
36 "Sou aristocrata por instinto" - disse Tocqueville em certa ocasião - "isto é, desprezo as massas. Amo com paixão a liberdade, a legalidade, o respeito aos direitos, porém não a democracia" (Tocqueville, 1988, p. 16).

${ }^{37}$ A “indústria” das ações judiciais pelos motivos mais banais demonstra esse fato. Essa "indústria de processos" exposta com freqüência na mídia é vulgarizada no cinema e nos seriados de TV quase que rotineiramente. No entanto, e apesar da fantasia mostrada nas telas, o fato reflete o domínio majoritário de um pensamento que se tornou "irresistível".

${ }^{38}$ Esse questionamento é feito por Marcelo Jasmin (1991, p. 53). 
as e de executá-las através de sua ação" (Jasmin, 1991, p. 50). Tocqueville comete o erro de todo analista que se filia estreitamente aos postulados da corrente denominada Realpolitik. "As lições da história - nos ensina Galbraith - não devem ser aceitas muito prontamente, nem devem ser aceitas sem questionamento" (Galbraith, 1992b, p. 1). Para fazer justiça, Tocqueville questiona - mas só até certo ponto - o novo modelo de democracia. Reconhece sua tendência indiscutivelmente universalizante, mas limita-se a procurar instrumentos que moderem ou mitiguem seus efeitos danosos sobre a sociedade. É incapaz, entretanto, de propor qualquer forma alternativa de superação do regime democrático individualista.

A lógica dos argumentos de Tocqueville, quer dizer, a construção de seu edifício teórico, desaba diante da oscilação das próprias bases em que se alicerça. O que não impede que o eco de suas observações se faça ouvir várias gerações subseqüentes. A democracia liberal é o ponto final do governo humano, proclama-se com arrogância hoje. Não há qualquer forma de alternativas a ela, diz, repetindo Tocqueville e Fukuyama, o filósofo Richard Rorty (apud George, 1992, p. 115). Nesse sentido, a liberdade, como é entendida por Tocqueville - um corpo intermediário instituído como obstáculo ao avanço da tirania da maioria-, dificilmente produzirá os efeitos desejados, à medida que esses corpos estarão influenciados pelos mesmos ideais da maioria. A liberdade tocquevilleana subordina-se, assim, aos princípios individualistas que dominam a mentalidade democrática moderna. Permanece, portanto, a liberdade, como um instrumento meramente formal e perseguido por uns poucos, sem condições de atender às exigências de uma época que clama no deserto pela sua adequação aos problemas sociais. A resposta às indagações formuladas inicialmente ficam momentaneamente suspensas, a menos que a democracia e a liberdade sejam encaradas por um outro ângulo que não o da igualdade de condições. Mas esta é uma questão para outra discussão.

Recebido para publicação em outubro/1998

MAGALHÃES, Fernando. The past threatens the future - Tocqueville and the perspective of individualistic democracy. Tempo Social; Rev. Sociol. USP, S. Paulo, 12(1): 141-164, May 2000.

UNITERIMS:

democracy, individualism, freedom,

Alexis de Tocqueville.
ABSTRACT: The history of democracy, in modern times, has coincided, in general terms, with the history of American democracy. Ever since Tocqueville pointed out the irresistible strength of this form of government, Western societies have done their best to adopt it as a model. It represents, to the great majority of contemporary people, the sole type of political regime that is able to lead 
humanity to its fulfilment - to conquer personal freedom and equality of opportunity. However, this equalitarian development is also responsible for the negative aspects of its functioning. Democracy runs the risk of transforming itself into its own antithesis. This would jeopardize its own system in two ways: by the action of its agents and by its specific excluding individualistic content. This paper tries to show, in a concise fashion, not only Tocqueville's concern over the destinies of this form of government, but also how equality, isolated from its material content (social), can generate a kind of discrimination which makes democratic society violent and unfair.

\section{REFERÊNCIASBIBLIOGRÁFICAS}

BAUDRILlAD, Jean. (1978) A l'ombre des majorités silencieuses ou la fin du social. Paris, Cahier d'Utopie.

Boвbio, Norberto. (1986) O futuro da democracia-uma defesa das regras dojogo. Rio de Janeiro, Paz e Terra.

. (1994) Destra e sinistra. Ragioni e significati di una distinzione politica. Roma, Donzelli Editore.

Chaur, Marilena. (1997) Cultura e democracia. São Paulo, Cortez.

Constant, Benjamin. (1980) Principes de politique. In: Gauchet, Marcel (org.). De la liberté chez les modernes. Paris, Hachette, p. 265-427.

DAHL, Robert. (1990) Um prefácio à teoria econômica. Rio de Janeiro, Jorge Zahar.

DAHrendorf, Ralf. (1981) Sociedade e liberdade. Brasília, UnB.

FuKuYAMA, Francis. (1992) The end of history and the last man. Harmondsworth, Penguin Books.

GalBRAITH, John Kenneth. (1992a) Questa è dittatura dei ricchi. L'Espresso, Roma, 17/05, p. 62-67. . (1992b) A cultura do contentamento. São Paulo, Pioneira.

George, Jean. (1992) L'ordre d'un monde americain. Pensée, Paris, (287): 111-116, mai-jun.

Hall, Stuart. (1998) A identidade cultural na pós-modernidade. Rio de Janeiro, DP\&A.

HARTz, Louis. (1955) The liberal tradition in America. An interpretation of American political thought since the revolution.Nova York, Harcourt, Brace and Company.

JARDIN, André. (1988) Alexis de Tocqueville, 1805-1859. México, Fondo de Cultura.

JASMIN, Marcelo. (1991) Individualismo e despotismo: A atualidade de Tocqueville. Presença, São Paulo, (16): 42-53. 
Lefort, Claude. (1991) Pensando o político - ensaio sobre democracia, revolução e liberdade. Rio de Janeiro, Paz e Terra.

LIPSOn, Leslie. (1966) A civilização democrática. Rio de Janeiro, Civilização Brasileira.

MAgAlHãEs, Fernando. (1993) Entre a aparência e a realidade: o "renascimento" da ideologia liberal. Revista Vozes, Petrópolis, 90(1): 3132, janeiro-fevereiro.

Matteucci, Nicola. (1981) Il liberalismo in una democrazia minacciata. Bolonha, Il Molino.

PRZEWORSKI, Adam. (1989) O capitalismo democrático na encruzilhada. In: . Capitalismo e social-democracia. São Paulo, Companhia das Letras, p. 241-260.

Quirino, Célia Galvão (1983) Liberdade e igualdade. Discurso, São Paulo, (15): 107-124.

Tocqueville, Alexis. (1986) De la démocratie en Amérique, Souvenirs et L'ancien régime et la révolution.Paris, Bouquins. . (1988) Igualdade social e liberdade política. São Paulo, Nerman.

Touraine, Alain. (1996) O que é democracia? Petrópolis, Vozes.

ViAnNA, Luís Werneck. (1993) Lições da América: o problema do americanismo em Tocqueville. Lua Nova, São Paulo, (30): 159-193. 